\title{
Endogenous levels of polyamines during cold storage of bird-of- paradise treated with biocides ${ }^{(1)}$
}

\author{
MARCOS RIBEIRO DA SILVA VIEIRA ${ }^{(2) *}$, GIUSEPPINA PACE PEREIRA LIMA ${ }^{(3)}$, LUIZA MARIA DE SOUZA \\ FERNANDES ${ }^{(3)}$, ANGELA VACARO DE SOUZA ${ }^{(4)}$, REGINALDO CONCEIÇÃO CERQUEIRA(5), \\ PAHLEVI AUGUSTO DE SOUZA(6), ARMANDO REIS TAVARES ${ }^{(7)}$, ADRIANO DO NASCIMENTO SIMÕES ${ }^{(8)}$
}

\begin{abstract}
This study aimed to analyse the endogenous levels of free polyamines putrescine (Put), spermidine (spd) and spermine (spm) under the effect of 8-HQC (8-hydroxyquinoline citrate) and chlorine during cold storage of bird-of-paradise floral scapes. Flowers were selected, labelled and randomly distributed in recipients for postharvest trials. The base of flower scapes was immersed with pulsing treatments (Control, 100 chlorine, 250 or $500 \mathrm{mg} \mathrm{L}^{-1} 8$ - HQC) for $48 \mathrm{~h}$, thereafter, stored at $10.5{ }^{\circ} \mathrm{C}$ and $90 \%$ relative humidity for a period of 12 days. Flower parts were sampled for polyamines analysis at day $0,4,8$ and 12 days during storage. All samples had higher Put levels than the control. Treatment with $500 \mathrm{mg} \mathrm{L}^{-1} 8-\mathrm{HQC}$ showed the highest Spd levels in bracts, while chlorine treatment had the highest Spm levels in stems.
\end{abstract}

Keywords: Strelitzia reginae, inflorescence, ornamental plant, postharvest, senescence.

\section{RESUMO}

Teores endógenos de poliaminas durante o armazenamento refrigerado de strelitzia tratados com biocidas O estudo teve como objetivo analisar os níveis endógenos de poliaminas livres (putrescina, espermidina e espermina) sob o efeito de 8-HQC (citrato de 8-hidroxiquinolina) e cloro durante o armazenamento frio de hastes florais de strelitzia. As flores foram selecionadas, rotuladas e distribuídas aleatoriamente em recepientes com os tratmentos pós-colheita. A base das hastes florais foi imersa em tratamentos de pulsing (Controle, 100 cloro, 250 ou $500 \mathrm{mg} \mathrm{L}^{-1}$ de 8 -HQC) durante $48 \mathrm{~h}$, depois armazenadas a $10,5^{\circ} \mathrm{C}$ e $90 \%$ de umidade relativa por 12 dias. Análises das partes das flores foram amostradas para análises de poliaminas no dia $0,4,8$ e 12 durante o armazenamento. Todas as amostras apresentaram maiores níveis de Put que o controle. O tratamento com $500 \mathrm{mg}$ de $\mathrm{L}^{-1}$ 8-HQC mostrou os maiores níveis de Spd em brácteas, enquanto o tratamento com cloro apresentou os maiores níveis de Spm em hastes.

Palavras-chave: Strelitzia reginae, inflorecência, plantas ornamentais, pós-colheita, senescência.

\section{INTRODUCTION}

The polyamines (PAs) are low-weight aliphatic molecules present in all organisms. The main PAs in higher plants are free putrescine (Put), spermidine (Spd) and spermine (Spm) or conjugated to phenolic acids and low-weight molecules (BOUCHEREAU et al., 1999; KUZNETSOV et al., 2007). PAs function as stress messengers in plant responses to different stress and play a important role on plant tolerance (GUPTA et al., 2013). Changes in PAs and ethylene levels were observed during senescence in plum (DE DIOS et al., 2006) and Hibiscus syriacus (SEO et al., 2007), and there is metabolic competition between ethylene and PAs under a biotic or abiotic high stress conditions (LI et al., 2004).

Biocides are used in pulsing and vase solutions in order to preserve the full postharvest longevity of cut flowers. The most widely held and effective biocides are esters of hydroxyquinoline (HQ) and their effectiveness as an biocide in cut flower handling solutions is widely know (DAMUNUPOLA and JOYCE, 2008). Sulphate (HQS) and citrate (HQC) forms of HQ are commonly used to increase cut flower longevity by acidifying the vase solution and acting as antitranspirant thus limiting water

DOI: http://dx.doi.org/10.14295/oh.v23i3.1101

${ }^{(1)}$ Received in 10/07/2017 and accepted in 26/09/2017

(2)Universidade Federal do Pará, Altamira-PA, Brazil. Corresponding author: m.r.s.v@hotmail.com

${ }^{(3)}$ Universidade Estadual Paulista "Julio de Mesquita Filho" (UNESP), Botucatu-SP, Brazil.

(4)Universidade Estadual Paulista “Julio de Mesquita Filho” (UNESP), Tupã-SP, Brazil.

${ }^{(5)}$ Universidade do Estado da Bahia, Pro-Reitoria de Extensão, Barreira-BA, Brazil.

${ }^{(6)}$ Instituto Federal de Educação, Ciência e Tecnologia do Ceará, Limoeiro do Norte-CE, Brazil.

${ }^{(7)}$ Instituto de Botânica, São Paulo-SP, Brazil.

${ }^{(8)}$ Universidade Federal Rural de Pernambuco, Serra Talhada-PE, Brazil.

Licensed by CC BY 4.0 
losses (DAMUNUPOLA and JOYCE, 2008). Chlorine (e.g. sodium hypochlorite, sodium dichloroisocyanuric acid; DICA) is an antimicrobial agent with a potential use as biocide in cut flower hydration solutions. Thus, chemical treatments as citrate compound 8-hydroxyquinoline (8HQC) and chlorine when combined with cold storage, can modify the endogenous levels of PAs.

Bird of Paradise (Strelitzia reginae) is native to South Africa. Modified leaves, at the end of the stalk form canoelike structures, four to eight inches long, from which flowers emerge forming a spectacular blossom. The petals are brilliant orange and contrasted with an arrow shaped tongue of blue (BURGESS, 2015). The vase life of bird paradize flowers varies from 6 to 15.5 days (JAROENKIT and PAULL, 2003). The longevity of bird of paradise flowers can be substantially increased by pulsing buds or flowers with a solution containing 10\% sucrose, $250 \mathrm{ppm} 8$ hydroxyquinoline citrate (8-HQC) and $150 \mathrm{ppm}$ citrate and storage at 6 to $7{ }^{\circ} \mathrm{C}$ (BMT, 2013).

This study aimed to analyze the endogenous levels of free PAs (Put, Spd and Spm) as possible senescence marker for bird-of-paradise cut flowers treated with biocides under cold storage.

\section{MATERIALS AND METHODS}

\section{Experiment}

Experiments were performed with fully opened bird-ofparadise flowers, collected in September from a cultivation field at São Manuel, São Paulo State, Brazil (2243'52"S and $\left.48^{\circ} 34^{\prime} 14^{\prime \prime} \mathrm{W}\right), 750 \mathrm{~m}$ above sea level. After flowers harvest in the morning, flowers scapes were cut and standardized to $80 \mathrm{~cm}$ and hydrated approximately for 10 to $15 \mathrm{~min}$.

The flowers were randomly transferred into containers (15-20 L) with 1.5 L of water. The base of flower scapes was immersed into pulse solution with 8-HQC (250 or 500 $\left.\mathrm{mg} \mathrm{L}^{-1}\right)$ and chlorine $\left(100 \mathrm{mg} \mathrm{L}^{-1}\right)$ for $48 \mathrm{~h}$, with $\mathrm{pH}$ ranging from 6.0 to 6.5 . Flowers on treatment control were also pulsed in tap water. Solutions were changed every $48 \mathrm{~h}$, to prevent the proliferation of microorganisms. The flowers were storaged at $10.5{ }^{\circ} \mathrm{C}$ with $90 \%$ relative humidity, for 12 days during the experiment. Floral sepals, petals, stems and bracts samples were collected at $0,4,8$ and 12 days for biochemical characterization of free PAs.

\section{Determination of polyamines}

Polyamines were determined by thin layer chromatography following the method described by Flores and Galston (1982), and adapted by Lima et al. (2008). Fresh material of sepals, petals, stems and bracts $(50 \mathrm{mg})$ were homogenized for $1 \mathrm{~min}$ in $5 \%(\mathrm{v} / \mathrm{v})$ cold perchloric acid (Merck), using a food homogenizer. After centrifugation for $20 \mathrm{~min}$ at $4{ }^{\circ} \mathrm{C}$, dansyl chloride (400 $\mu \mathrm{L}$; Sigma 95\%), satured sodium carbonate (200 $\mu \mathrm{L})$ were added to the supernatant. Proline $\left(100 \mathrm{mg} \mathrm{L}^{-1}\right.$; Sigma) was added to the supernatant after $1 \mathrm{~h}$ to stop the reaction and the solution was brought to $60{ }^{\circ} \mathrm{C}$. The mixture was maintained in the dark for $30 \mathrm{~min}$ at ambient temperature. Toluene was used to extract dansylated PAs and aliquots were applied onto thin layer chromatography plates (glass plates coated with $60 \mathrm{G}$ silica Gel - Merch; $20 \times 20$ ). Separation was carried out in laboratory bowls containing chloroform: triethylamine (Merck) (10:1, v/v). Put (Sigma), Spd (Sigma) and Spm (Sigma) standards were subjected to the same process. The entire procedure was monitored under UV light (254 nm). PAs were quantified by comparison against standards, which were also applied onto to the plates, by fluorescence emission spectroscopy (Physics 3600 - Advanced Physics Lab-1 - Summer, excitation at $350 \mathrm{~nm}$ and emission measurement at $495 \mathrm{~nm}$ ) in a Video Documentation System, using the Image Master version 2.0 software program.

\section{Statistical analysis}

The experimental design was randomized, with four pulsing treatments (control, $100 \mathrm{mg} \mathrm{L}^{-1}$ chlorine, $250 \mathrm{mg}$ $\mathrm{L}^{-1} 8$-HQC or $500 \mathrm{mg} \mathrm{L}^{-1} 8$-HQC), four tissues (sepals, petals, stems and bracts) and four harvest periods $(0,4,8$ and 12 days), consisting of seven replicates and five floral samples each. Analysis of variance was performed to detect differences between treatments means using SAS/STAT software (2008 version).

\section{RESULTS}

Put levels in sepals were constant on pulsing treatments (Figure 1A). High Put levels were observed in sepals after pulsed/treated with $100 \mathrm{mg} \mathrm{L}^{-1}$. Put levels in sepals were above $10 \mu \mathrm{g} \mathrm{g}^{-1}$ and below $40 \mu \mathrm{g} \mathrm{g}^{-1}$, independent of the application of biocides (Figure $1 \mathrm{~A}$ ). Put levels in petals (Figure 1B) of treatment $100 \mathrm{mg} \mathrm{L}^{-1}$ chlorine had a sharp decline at the beginning of the experiment. Treatment 500 $\mathrm{mg} \mathrm{L}^{-1} 8$-HQC had higher Put levels on the fourth day in all plant tissues, when compared to day zero, when started to decline throughout the storage period. Petals treated with $250 \mathrm{mg} \mathrm{L}^{-1} 8$-HQC showed higher Put levels on the eighth day when compared to previous periods and decreased until the twelfth day. Stems in the Control had higher Put levels during storage (Figure 1C). Put levels in stems treated with $100 \mathrm{mg} \mathrm{L}^{-1}$ chlorine remained constant until the eight day, and an increasing tendency was observed (Figure 1C). Bracts of chlorine treatment showed higher Put levels until the eighth day and then started to decline. 

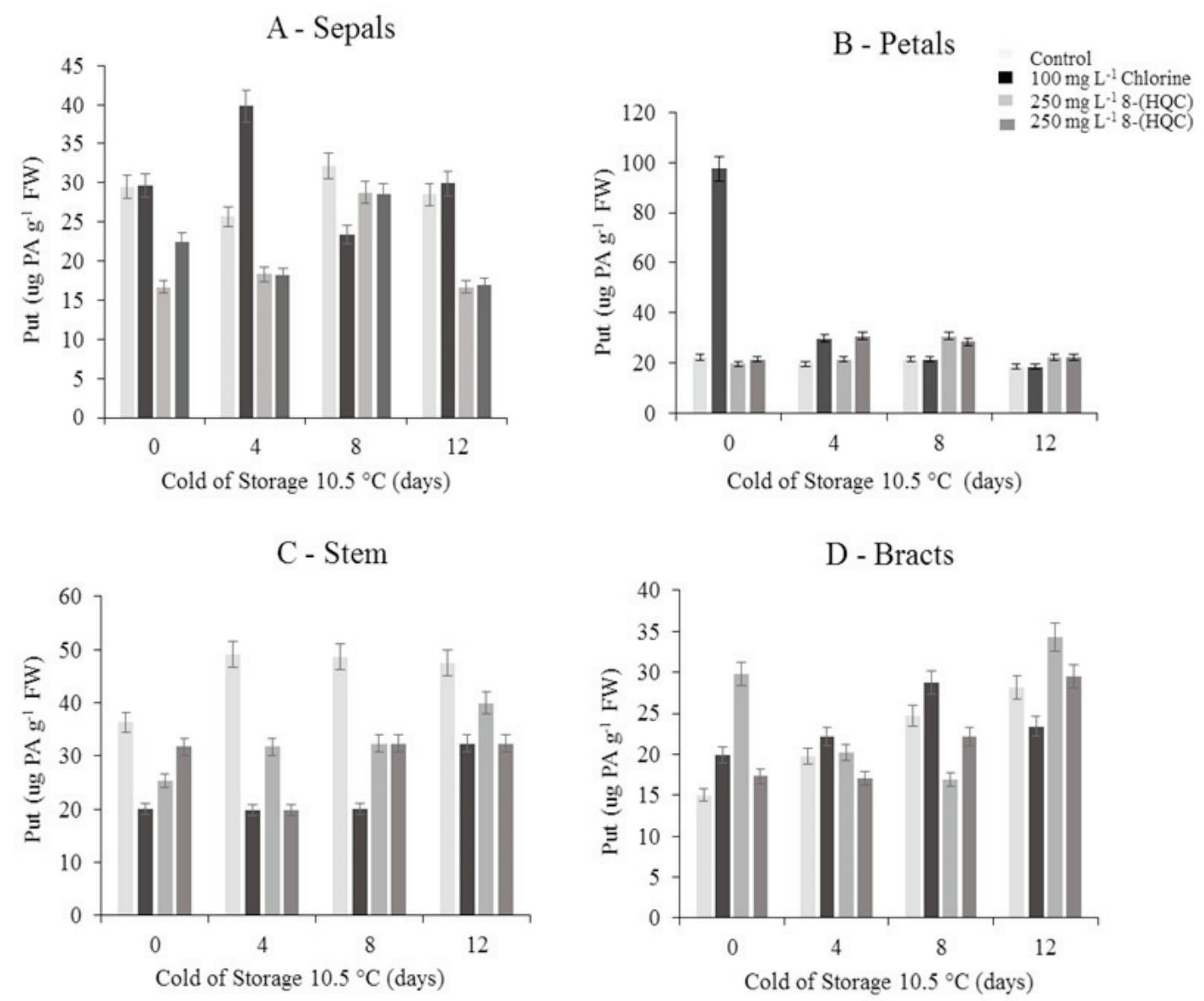

Figure 1. Putrescine (Put) level ( $\mu \mathrm{g} \mathrm{g}^{-1}$ fresh weight) in bird-of-paradise (sepals, petals, stem and bracts) submitted four pulsing treatments during storage at $10.5^{\circ} \mathrm{C}$ for twelve days.

Spd levels in sepals were higher than Put levels (Figure 2A). Sepals showed Spd levels above $80 \mu \mathrm{g} \mathrm{g}^{-1}$ and below
$40 \mu \mathrm{g} \mathrm{g}^{-1}$. Petals (Figure 2B), likewise to Put levels, Spd levels in petals declined on the treatment $100 \mathrm{mg} \mathrm{L}^{-1}$. 


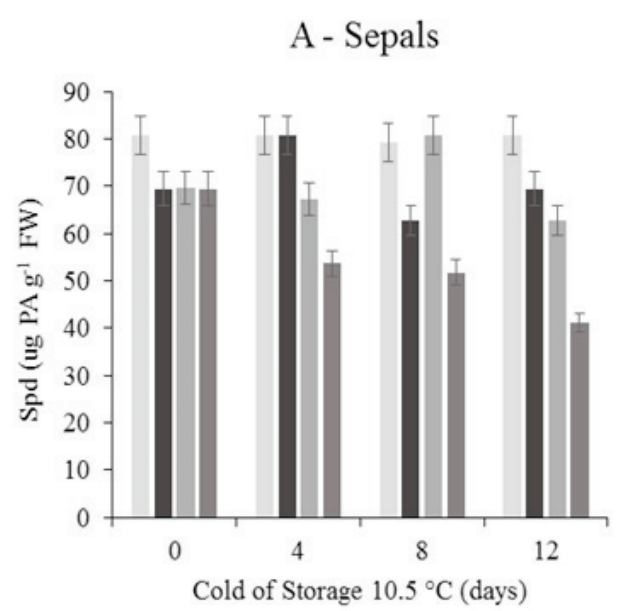

C - Stem

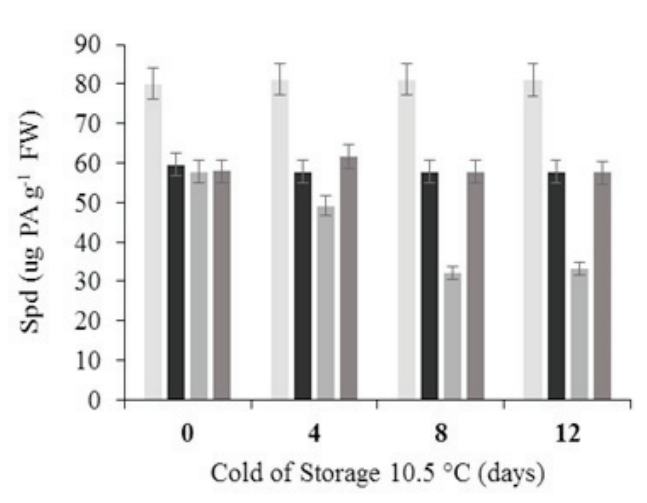

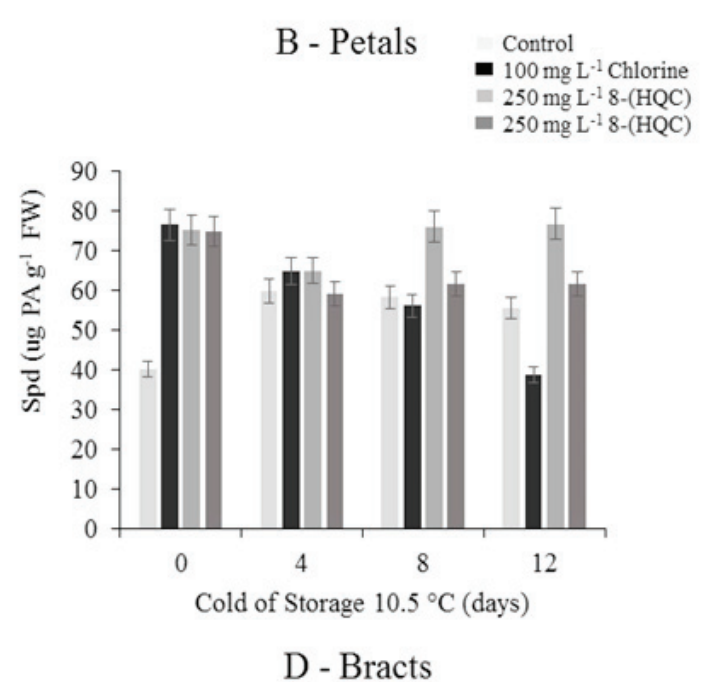

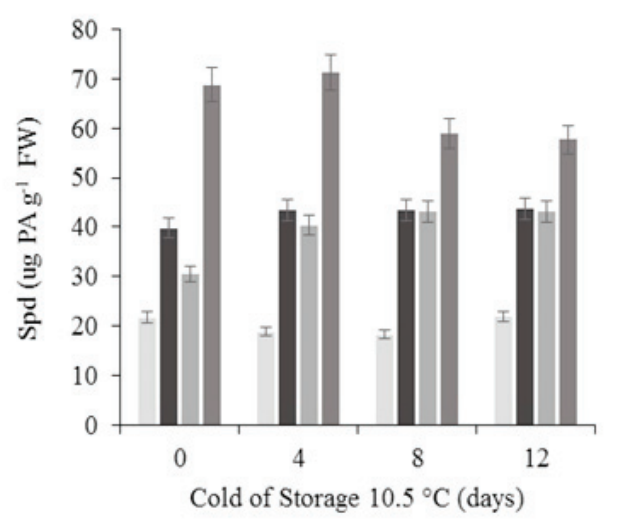

Figure 2. Spermidine (Spd) level ( $\mu \mathrm{g} \mathrm{g}^{-1}$ fresh weight) in bird-of-paradise (sepals, petals, stem and bracts) submitted four pulsing treatments during storage at $10.5^{\circ} \mathrm{C}$ for twelve days.

Control showed higher Spd levels in relation to the starting point and a decline over the experiment period. Stems had higher Spd levels (Figure 2C) on Control. Bracts of treatment $100 \mathrm{mg} \mathrm{L}^{-1}$ chlorine had high Spd levels on day four when compared to day zero, remaining constant. Spd levels in stem of treatment $250 \mathrm{mg} \mathrm{L}^{-1} 8$-HQC in the, a declined until eighth day, followed by an increase. Higher Spd levels in bracts of treatment with $500 \mathrm{mg} \mathrm{L}^{-1}$ 8-HQC was observed at fourth day (Figure 2D), from this point, there was a sharp drop in Spd levels. In contrast, Spd levels increased in bracts during the storage period in $250 \mathrm{mg} \mathrm{L}^{-1}$ 8-HQC treatment.

Spm levels in sepals on treatment $500 \mathrm{mg} \mathrm{L}^{-1} 8$-HQC increase (Fig. 3A), except at twelfth day. Spm levels in sepals on treatment $250 \mathrm{mg} \mathrm{L}^{-1} 8-\mathrm{HQC}$ decline until eighth day, increasing after this point. 
A - Sepals

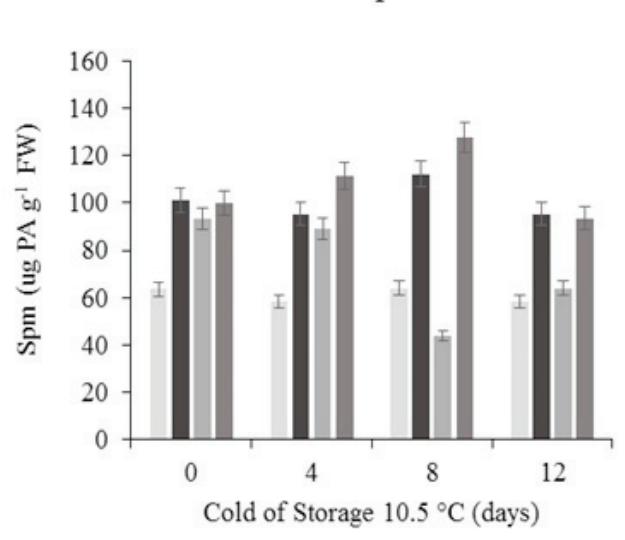

C - Stem

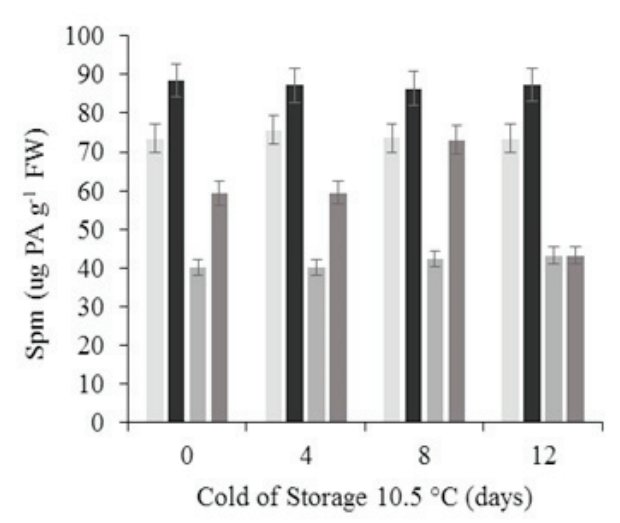

B - Petals

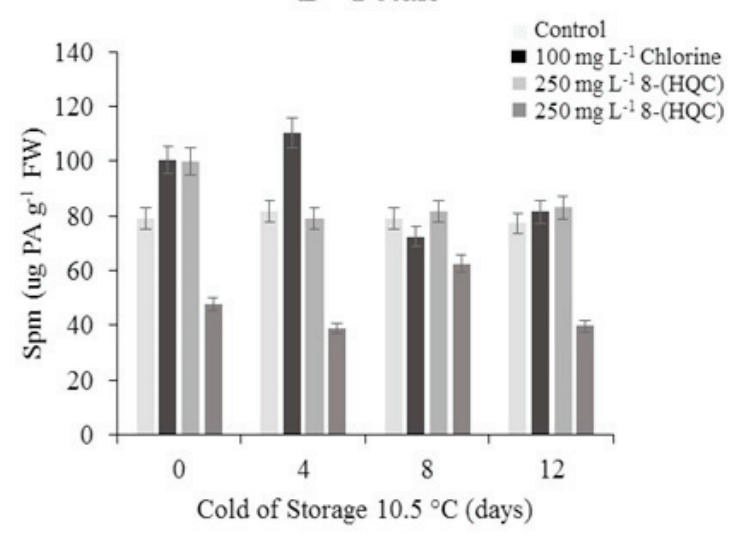

D - Bracts

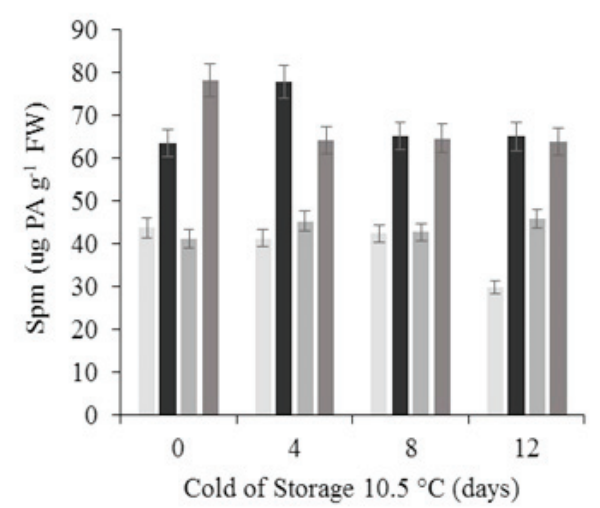

Figure 3. Spermine (Spm) level ( $\mu \mathrm{g} \mathrm{g}^{-1}$ fresh weight) in bird-of-paradise (sepals, petals, stem and bracts) submitted four pulsing treatments during storage at $10.5^{\circ} \mathrm{C}$ for twelve days.

Petals in the chlorine treatment showed higher Spm levels from the fourth day, and decreased until the end (Figure 3B). Spm levels of the control decreased from the fourth day. Spm levels in stems on $250 \mathrm{mg} \mathrm{L}^{-1} 8$-HQC increased (Figure 3C), while on $500 \mathrm{mg} \mathrm{L}^{-1} 8$-HQC showed a decline at the end of the experimention. Stems from treatment $100 \mathrm{mg} \mathrm{L}^{-1}$ chlorine had the highest Spm levels. Bracts showed the highest Spm levels on treatements 100 $\mathrm{mg} \mathrm{L}^{-1}$ chlorine and $500 \mathrm{mg} \mathrm{L}^{-1} 8$-HQC (Figure 3D). Bracts of treatment $250 \mathrm{mg} \mathrm{L}^{-1} 8$-HQC, increased levels at the end of the experiment, when compared with previous periods.

According to the average ratings (Table 1) of visual appearance of bird-of-paradise (sepals, petals and bracts) the longevity of floral scapes are between 6 and 8 days. Treatment $100 \mathrm{mg} \mathrm{L}^{-1}$ chlorine was more efficient to maintain bird-of-paradise for sepals, while for petals and bracts $100 \mathrm{mg} \mathrm{L}-1$ chlorine and $250 \mathrm{mg} \mathrm{L}-1$ 8-HQC were more efficient (Table 1). 
Table 1. Medium between the solutions interaction and bird-of-paradise in relation longevity

\begin{tabular}{|c|c|c|c|}
\hline Treatments $\left(\mathbf{1 0 . 5}^{\mathbf{}} \mathbf{C}\right)$ & Sepals & Petals & Bracts \\
\hline Water & $2.05 \mathrm{a}$ & $1.97 \mathrm{ab}$ & $1.95 \mathrm{ab}$ \\
\hline $100 \mathrm{mg} \mathrm{L}^{-1}$ cloro & $2.05 \mathrm{a}$ & $2.05 \mathrm{ab}$ & $2.03 \mathrm{ab}$ \\
\hline $250 \mathrm{mg} \mathrm{L}-18-\mathrm{HQC}$ & $1.85 \mathrm{~b}$ & $2.12 \mathrm{~b}$ & $2.07 \mathrm{~b}$ \\
\hline $500 \mathrm{mg} \mathrm{L}-18-\mathrm{HQC}$ & $1.83 \mathrm{~b}$ & $1.92 \mathrm{a}$ & $1.92 \mathrm{a}$ \\
\hline
\end{tabular}

Means followed by the same columns do not differ by Tukey test $5 \%$ probability

\section{DISCUSSION}

The highest Put levels was observed on treatment Control, except in the petals. $500 \mathrm{mg} \mathrm{L}^{-1} 8$-HQC induced higher Spd levels in the sepals, stems and bracts compared with petals. Higher Spm levels were observed on chlorine treatment in the sepals when compared to stems and bracts. Pulsing $\mathrm{x}$ tissue $\mathrm{x}$ harvest periods interaction showed a decrease of Put levels during exposure to cold with exception of petals. Put levels in petals and stems of treatment $500 \mathrm{mg} \mathrm{L}^{-1} 8$-HQC declined since the fourth day, probably due to the oxidation of such amine (BOUCHEREAU et al., 1999). These results are comparable with the data reported by Vieira et al. (2010) for chrysanthemum Faroe (Dendranthema grandiflorium), with lower Put levels during cold storage $\left(10{ }^{\circ} \mathrm{C}\right.$ for 48 hours), but without the use of pulsing solution during the post-harvest. Diamine levels are not affected by treatments at lower temperatures, such as Groppa and Benavides (2008) studies, which reported that Put levels did not change significantly in cucumber cultivars. PAs can vary due to plant organ, degree of ripeness and postharvest treatments during cold exposure as reported for pepper, cucumber, zucchini and citrus (orange and lemon) (BARRACHINA et al., 2000; CHATTOPADHAYAY et al., 2002; NAYYAR and CHANDER, 2004). Changes in PAs levels may be a consequence of stress and/or environmental factors, pointing to their possible role as biochemical markers of metabolic events, such as senescence (YAMAGUCHI et al., 2007).

Spd levels in sepals and bracts treated with $500 \mathrm{mg} \mathrm{L}^{-1}$ 8-HQC and petals treated with $100 \mathrm{mg} \mathrm{L}^{-1}$ chlorine declined of during refrigerated storage. Our results are consistent with the literature reports, for exemple, when flower senescence starts there is a decrease of PAs levels and this effect is attribute to the competition between PAs and ethylene (BOUCHEREAU et al., 1999). The catabolism of Spd through the action of oxidase enzymes (produces pyrroline with diaminopropane and $\mathrm{H}_{2} \mathrm{O}_{2}$ ) would be the most important factor for lower PAs (SMITH, 1985). The PAs degradation occur by PAs oxidases, generating $\mathrm{H}_{2} \mathrm{O}_{2}$, substrate for the peroxidase (BOUCHEREAU et al., 1999; CONA et al., 2006).

Put levels increased in the bracts at eighth day when pulsed with 8-HQC and Control and this effect can be attributed to the senescence, as a reduction in $\mathrm{Spm}$ and $\mathrm{Spd}$ levels and accumulation of Put (BOUCHEREAU et al., 1999; CAPELL et al., 2004). However, the highest levels of amines were observed on Spd and Spm in sepals. Changes in PAs content can be described as protective responses intended to maintain the structural integrity of membrane and cell walls (EDREVA, 1997). The relationship between free endogenous polyamines (PAs) and ethylene during growth and ripening of pear fruit, was monitored and after harvest, Put levels were higher than Spd and Spd levels (MORA et al., 2005). An intimate connection between polyamines and floral development makes it possible to establish some physiological or biochemical markers using the individual polyamine, the ratios or the total polyamines (LIU et al., 2000). Polyamines have been reported to delay senescence in various tissues and species; however, spermine and putrescine did not have delay senescence in carnation flowers; indeed, on some treatments they advanced senescence (DOWNS and LOVELL, 1986).

The increase of PAs endogenous levels in several species are correlated with the reduction of injuries caused by lower temperatures (KRAMER and WANG, 1989), once these amines act to remove the reactive oxygen species and also support the stabilization of membranes (LARHER et al., 2003; GROPPA and BENAVIDES, 2008). Yamamoto et al. (2012) provided further evidence on the physiological importance of Spd in conveying chilling-stress tolerance when exposed rice seedlings to low temperature and observed that Put and Spd levels increased in leaf blades and a positive correlation between leaf chlorophyll fluorescence values and leaf Spd contents. As opposed to cold storage, under high temperatures there would be a reduction in PAs levels, affecting cell division (POLJAKOFF-MAYBER and LERNER, 1994). The variations in endogenous Put, Spd and Spm levels in our study were not related to $8-\mathrm{HQC}$ and chlorine pulsing, but to the cold storage of floral scapes of bird-of-paradise at $10.5^{\circ} \mathrm{C}$, confirming data reported by Barrachina et al. (2000), Chattopadhayay et al. (2002) and Nayyar and Chander (2004) that PAs levels may vary with the post-harvest treatment, maturity stage and organ of the plant.

Deleterious effects on floral scapes of bird-of-paradise due to treatment $500 \mathrm{mg} \mathrm{L}^{-1} 8$ 8-HQC, showing lower floral scapes quality during the experimentation period. Similarly in Achillea flowers, treatment with pulse solution of 500 $\mathrm{mg} \mathrm{L}^{-1} 8$-HQC for 24 hours reduced vase life (REDMAN et al., 2002), may be due to excess acidification of the solution (SHIVA and BHATTACHARJEE, 2003). 


\section{CONCLUSIONS}

The treatments with chlorine or HQC, concentration independent, become more unstable Put, Spm and Spd levels on the stem. The same instability occurred in the sepals for Spd. Differently it happened in the bracts, in which the treatments with Chlorine or HQC, concentration independent, induced high levels of Spd and Spm. The concentrations of $250 \mathrm{mg} \mathrm{L}^{-1} 8$-HQC or $100 \mathrm{mg} \mathrm{L}^{-1}$ of chlorine provided greater longevity for sepals, petals and bracts in of bird-of-paradise flowers refrigerated. Pulsing treatments during cold storage at $10.5^{\circ} \mathrm{C}$ in floral scapes of bird-of-paradise showed no clear relation vase life and endogenous levels of PAs. We observed that Spd and Spm levels were higher than that Put under low temperature storage.

\section{ACKNOWLEDGEMENTS}

The authors acknowledge National Counsel of Technological and Scientific Developmen-CNPq and Fundação de Amparo a Ciência e Tecnologia de Pernambuco (FACEPE/APQ-0053-5.01/14) for the financial support to this work.

\section{AUTHORS CONTRIBUTIONS}

MRSV: conception and design of the research, obtaining data, analyze and interpretation of data, statistical analysis, write and critically analyses of manuscript. GPPL: conception and design of the research, analyze and interpretation of data, statistical analysis, write and critically analyses of manuscript. LMSF: analyze and interpretation of data, statistical analysis, write and critically analyses of manuscript. AVS: analyze and interpretation of data, statistical analysis, write and critically analyses of manuscript. RCC: analyze and interpretation of data, statistical analysis, write and critically analyses of manuscript. PAS: analyze and interpretation of data, statistical analysis, write and critically analyses of manuscript. ART: analyze and interpretation of data, write and critically analyses of manuscript. ANS: analyze and interpretation of data, write and critically analyses of manuscript.

\section{REFERENCES}

BARRACHINA, A.C.; GARRIDO, D.V.; ROMERO, D.M.; MULA, M.S.; CARBONELL, F.B.; SANCHEZ, F. M.; BALLESTEROS, F.R. Polyamines: biosynthesis, metabolism, and their role in ripening and postharvest handling of fruits. Food Science and Technology International-Frederick, v.6, n.2, p.85-96, 2000.

BMT 2013. Bird-of-paradise. 2013. Available at: $<$ http:// www.cargohandbook.com/index.php/Bird-of-paradise $>$. Accessed in: September $26^{\text {th }} 2017$.
BOUCHEREAU, A.; AZIZ, A.; LARHER, F.; MARTINTANGUY, J. Polyamines and environmental challenges: recent development. Plant Science, v.140, n.2, p.103-125, 1999. DOI: <10.1016/S0168-9452(98)00218-0>

BURGESS, C. 2015. Bird of Paradise. Avaible at: < http:// www.clemson.edu/extension/hgic/plants/indoor/flowering/ hgic1562.html >. Accessed in: September $26^{\text {th }} 2017$.

CAPELL, T.; BASSIE, L.; CHRISTOU, P. Modulation of the polyamine biosynthetic pathway in transgenic rice confers tolerance to drought stress. Proceedings of the National Academy of Sciences of the United States of America, v.101, n.26, p.9909-9914, 2004. DOI: <10.1073/ pnas.0306974101>

CHATTOPADHAYAY, M.K.; TIWARI, B.S., CHATTOPADHYAY, G., BOSE, A., SENGUPTA, D.N.; GHOSH, B. Protective role of exogenous polyamines on salinity stressed rice (Oryza sativa) plants. Physiologia Plantarum, v.116, n.2, p.192-199, 2002. DOI: <10.1034/ j.1399-3054.2002.1160208.x>

CONA, A.; REA, G.; ANGELINI, R.; FEDERICO, R.; TAVLADORAKI, P. Functions of amine oxidases in plant development and defence. Trends in Plant Science, v.11, n.2, p.80-88, 2006. DOI: <10.1016/j.tplants.2005.12.009>

DAMUNUPOLA, J.W.; JOYCE, D.C. When is a vase solution biocide not, or not only, antimicrobial?. Journal of the Japanese Society for Horticultural Science, v.77, n.3, p.211-228, 2008. DOI: <10.2503/jjshs1.77.211>

DE DIOS, P.; MATILLA, A.J.; GALLARDO, M. Flower fertilization and fruit development prompt changes in free polyamines and ethylene in damson plum (Prunus insititia L.). Journal of Plant Physiology, v.163, n.1, p.86-97, 2006. DOI: $<10.1016 /$ j.jplph.2005.03.007>

DOWNS, C.G.; LOVELL, P.H. Carnations: relationship between timing of ethylene production and senescence of cut blooms. New Zealand Journal of Experimental Agriculture, v.14, n.3, p.331-338, 1986. DOI: <10.1080/ 03015521.1986.10423048>

EDREVA, A. Tobacco polyamines as affected by stresses induced by different pathogens. Biologia Plantarum, v.40, n.2, p.317-320, 1997. DOI: <https://doi. org/10.1023/A:1001093209229>

FLORES, H.E.; GALSTON, A.W. Analysis of polyamines in higher plants by high performance liquid chromatography. Plant Physiology, v.69, n.3, p.701-706, 1982.

GROPPA, M.D.; BENAVIDES, M.P. Polyamines and abiotic stress: recent advances. Amino Acids, v.34, n.1, p.35-45, 2008. DOI: <10.1007/s00726-007-0501-8> 
GUPTA, K.; DEY, A.; GUPTA, B. Plant polyamines in abiotic stress responses. Acta Physiologiae Plantarum, v.35, n.7, p.2015-2036, 2013.

JAROENKIT, T.; PAULL, R.E. Postharvest handling of Heliconia, red ginger, and bird-of-paradise. HortTechnology, v.13, n.2, p.259-266, 2003.

KRAMER, G.F.; WANG, C.Y. Correlation of reduced chilling injury with increased spermine and spermidine levels in zucchini squash. Physiologia Plantarum, v.76, n.4, p.479-484, 1989. DOI: <10.1111/j.1399-3054.1989. tb05466.x>

KUZNETSOV, V.; SHORINA, M.; ARONOVA, E.; STETSENKO, L.; RAKITIN, V.; SHEVYAKOVA, N. $\mathrm{NaCl}$-and ethylene-dependent cadaverine accumulation and its possible protective role in the adaptation of the common ice plant to salt stress. Plant Science, v.172, n.2, p.363-370, 2007. DOI: <10.1016/j.plantsci.2006.09.012>

LARHER, F.R.; AZIZ, A.; GIBON, Y.; TROTEL-AZIZ, P.; SULPICE, R.; BOUCHEREAU, A. An assessment of the physiological properties of the so-called compatible solutes using in vitro experiments with leaf discs. Plant Physiology and Biochemistry, v.41, n.6, p.657-666, 2003. DOI: <10.1016/S0981-9428(03)00076-7>

LI, C.Z.; JIAO, J.; WANG, G.X. The important roles of reactive oxygen species in the relationship between ethylene and polyamines in leaves of spring wheat seedlings under root osmotic stress. Plant Science, v.166, n.2, p.303-315, 2004. DOI: <https://doi.org/10.1023/ B:GROW.0000014890.97789.fe>

LIMA, G.P.P.; DA ROCHA, S.A.; TAKAKI, M.; RAMOS, P.R.R.; ONO, E.O. Comparison of polyamine, phenol and flavonoid contents in plants grown under conventional and organic methods. International Journal of Food Science \& Technology, v.43, n.10, p.1838-1843, 2008. DOI: $<10.1111 /$ j.1365-2621.2008.01725.x>

LIU, K.; FU, H.; BEI, Q.; LUAN, S. Inward potassium channel in guard cells as a target for polyamine regulation of stomatal movements. Plant Physiology, v.124, n.3, p.1315-1326, 2000. DOI: <https://doi.org/10.1104/ pp.124.3.1315>

MORA, O.F.; TANABE, K.; ITAI, A.; TAMURA, F.; ITAMURA, H. Relationship between endogenous free polyamine content and ethylene evolution during fruit growth and ripening of Japanese pear (Pyrus pyrifolia Nakai). Japan Society for Horticultural Science, v.74, p.221-227, 2005. DOI: <10.2503/jjshs.74.221>
NAYYAR, H.; CHANDER, S. Protective effects of polyamines against oxidative stress induced by water and cold stress in chickpea. Journal of Agronomy and Crop Science, v.190, n.5, p.355-365, 2004. DOI: $<10.1111 /$ j.1439-037X.2004.00106.x>

POLJAKOFF-MAYBER, A.; LERNER, H.R. Plants in saline environments. In: PESSARAKLI, M. (Ed.). Handbook of plant and crop stress. New York: Marcel Dekker, 1994. 65-96p.

REDMAN, P.B.; DOLE, J.M.; MANESS, N.O.; ANDERSON, J.A. Postharvest handling of nine specialty cut flower species. Scientia Horticulturae, v.92, n.3, p.293-303, 2002. DOI: <10.1016/S0304-4238(01)00294$1>$

SEO, S.G.; SHIM, S.I.; USUI, K.; FUJIHARA, S. Analysis of polyamines, 1-aminocyclopropane-1carboxylic acid and their conjugated forms in floral organs of Hibiscus syriacus L. Journal of the Japan Society for Horticultural Science, v.76, p.149-156, 2007. DOI: $<10.2503 /$ jjshs.76.149>

SHIVA, K.N.; BHATTACHARJEE, S.K. Effect of chemical preservatives on vase life of cut rose. South Indian Horticulture, v.51, n.1/6, p.232-236, 2003. DOI: $<$ https://doi.org/10.1016/j.jssas.2011.06.002>

SMITH, T.A. Polyamines. Annual Review of Plant Physiology, v.36, n.1, p.117-143, 1985. DOI: <10.1146/ annurev.pp.36.060185.001001>

VIEIRA, M.R.S.; FREIRE, F.J.; MEDEIROS, D.C.; MOURA, F.B.; AMORIM, T.L.; SIMÕES, A.N. Polyamines, peroxidase and proteins involved in the senescence process. African Journal of Biotechnology, v.12, n.14, p.1571-1575, 2013. DOI: <10.5897/ AJBX12.012>

YAMAGUCHI, K.; TAKAHASHI, Y.; BERBERICH, T.; IMAI, A.; TAKAHASHI, T.; MICHAEL, A.J.; KUSANO, T. A protective role for the polyamine spermine against drought stress in Arabidopsis. Biochemical and Biophysical Research Communications, v.352, n.2, p.486-490, 2007. DOI: <10.1016/j.bbrc.2006.11.041>

YAMAMOTO, A.; SHIM, I.S.; FUJIHARA, S. Chillingstress responses by rice seedlings grown with different ammonium concentrations and its relationship to leaf spermidine content. Journal of Plant Biology, v.55, n.3, p.191-197, 2012. DOI: <10.1007/s12374-011-0072-9> 